\title{
ANALISA TEGANGAN, REGANGAN DAN DEFORMASI PADA PERKERASAN KONVENSIONAL DAN PERKERASAN PORUS
}

\author{
Mukhammad Mukhlis ${ }^{1}$, Ludfi Djakfar ${ }^{2}$, Harimurti $^{3}$ \\ ${ }^{1}$ Mahasiswa / Program Magister / Teknik Sipil / Fakultas Teknik / Universitas \\ Brawijaya Malang \\ ${ }^{2,3}$ Dosen / Teknik Sipil / Fakultas Teknik / Universitas Brawijaya Malang \\ J1. MT Haryono 167, Malang 65145, Indonesia \\ Korespondensi: khlis1221@gmail.com
}

\begin{abstract}
In Indonesia generally use conventional flexible pavement, where the ability to pass water is not good. One prevention effort is using porous flexible pavement. To determine the effect of stress, strain, and deformation on porous and conventional pavement, a semi-field pavement study was conducted and focused on improving track performance. Semi-field scale is an analytical method that using a certain scale that can represent the actual conditions that occur in the field, both on the load, material, and thickness. From the measurement results, the value of stress and strain increased along with the increasing number of tracks. Meanwhile, the deformation on the surface of the asphalt due to the passing wheel load increases as the number of tracks increases.
\end{abstract}

Keywords: Conventional flexible pavement, deformation, porous flexible pavement, strain, stress

\section{PENDAHULUAN}

Jenis perkerasan lentur yang digunakan di Indonesia pada umumnya adalah perkerasan konvensional dengan standar Bina Marga. Tipikal utama dari perkerasan lentur konvensional ini adalah kemampuannya dalam meloloskan air kurang baik sehingga pada musim hujan jalan rentan terhadap kerusakan dan dapat mengakibatkan terjadinya genangan atau banjir. Salah satu upaya pencegahan atas permasalahan tersebut adalah menggunakan aspal porus. Perkerasan porus atau perkerasan tembus air adalah perkerasan yang direncanakan dengan menggunakan bahan material yang mampu meloloskan aliran air ke dalam lapisan tanah di bawahnya. Perkerasan konvensional memiliki sifat kedap terhadap air, sehingga air tidak mudah meresap ke lapisan di bawahnya

Konsep penyaluran beban pada perkerasan yaitu beban menyebar ke bawah sejauh ketebalan perkerasan. Pengaruh beban akan semakin kecil seiring dengan bertambahnya kedalaman. Tegangan dan regangan yang diterima oleh perkerasan akibat beban mengalami pengurangan dan pada akhirnya tidak merasakan pengaruh beban tersebut sehingga nilai tegangan dan regangan yang terjadi dapat diabaikan.

Dalam perencanaan struktur perkerasan aspal porus, selain material bahan penyusunnya, terdapat pula aspek lain yang perlu diperhatikan, yaitu perilaku perkerasan dalam menerima beban yang ditunjukkan dengan tegangan, regangan, dan deformasi. Untuk mengetahui tegangan, regangan, dan deformasi pada perkerasan porus dan konvensional, maka peneliti ingin melakukan pengujian pada dua perkerasan tersebut dengan metode skala semi lapangan dan fokus pada peningkatan kinerja jumlah lintasan.

Adapun tujuan dari penelitian ini adalah:

1. Untuk membuktikan adanya hubungan perilaku tegangan dan regangan pada lapisan perkerasan konvensional dan perkerasan porus yang diukur dengan menggunakan alat skala semi lapangan

2. Untuk menguji perbedaan atau persamaan deformasi yang terjadi pada perkerasan konvensional dan perkerasan porus

3. Untuk mengetahui perbandingan antara tegangan dan regangan antara perkerasan konvensional dan perkerasan porus. 


\section{STUDI TERDAHULU}

Pengujian repitisi beban roda dilakukan dengan menggunakan alat Loaded wheel tracker (LWT) yang akan memberikan gambaran seberaba baik kinerja perkerasan aspal porus dengan memperhitungkan kedalaman rutting akibat dari beban lintasan yang berulang. [5]

Pengujian tarik tidak langsung untuk modulus kekakuan dilakukan dengan menggunakan alat Universal Test Machine (UTM) yang memberikan beban berulang sepanjang diameter vertikal benda uji. [6]

Regangan perkerasan porus menggunakan skala semi lapangan berbanding terbalik dengan nilai tegangan yaitu semakin menurun dengan bertambahnya jumlah lintasan beban saat berjalan ataupun berhenti. [3]

Regangan yang diperoleh dari pengukuran dengan skala semi lapangan akibat beban statis dan beban dinamis memiliki perbedaan dimana regangan yang dihasilkan oleh beban dinamis lebih kecil daripada regangan akibat beban statis. Hal ini dikarenakan adanya efek perlakuan beban yang berbeda . [1]

Tegangan yang terjadi pada lapis pondasi merupakan tegangan tekan dimana nilai maksimum berada tepat di bawah roda dan akan semakin berkurang seiring dengan jaraknya terhadap beban roda. Namun pada beberapa kondisi, tegangan maksimum yang terjadi tidak tepat berada di bawah roda, dan tegangan yang terjadi berupa tegangan tarik yang bernilai negatif. [4]

\section{METODOLOGI PENELITIAN}

Pada penelitian ini digunakan beban sebesar $20 \mathrm{~kg}$ sebagai asumsi beban kendaraan dalam keadaan overload.

Pengukuran dilakukan secara dinamis dan statis. Pengukuran dinamis adalah pengukuran saat beban berjalan (dinamis) dilakukan berulang tiap lintasan hingga 5000 lintasan. Pengukuran statis adalah pengukuran saat beban berhenti (statis) setiap 100 lintasan, dan dilakukan hingga mencapai 5000 lintasan

\subsection{Diagram Tahapan Penelitian}

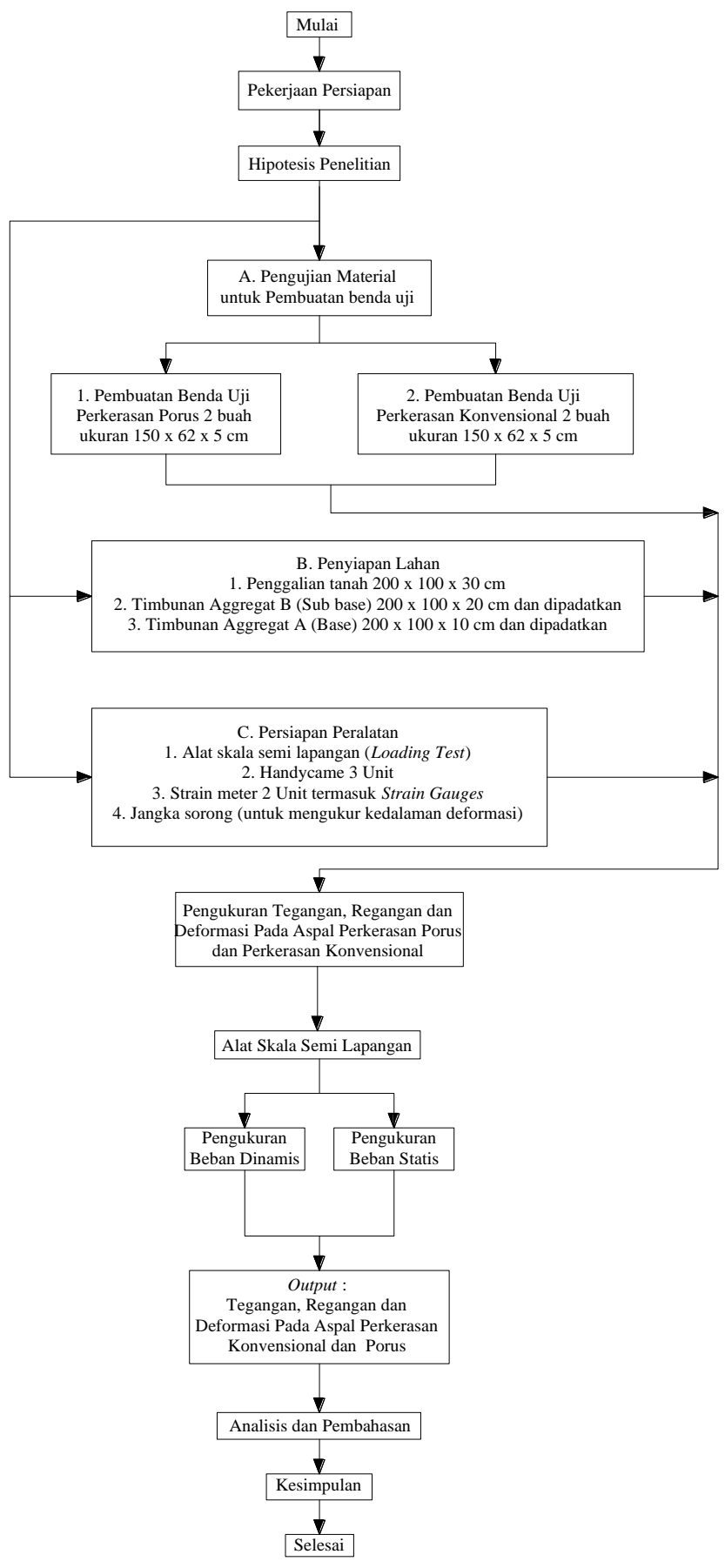

Gambar 1. Diagram tahapan penelitian 


\subsection{Pengembangan Alat}

a. Mesin Penguji

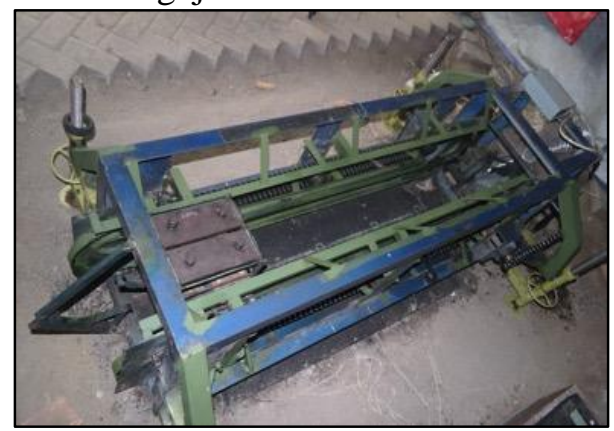

Gambar 2. Mesin penguji

b. Strain Gauge

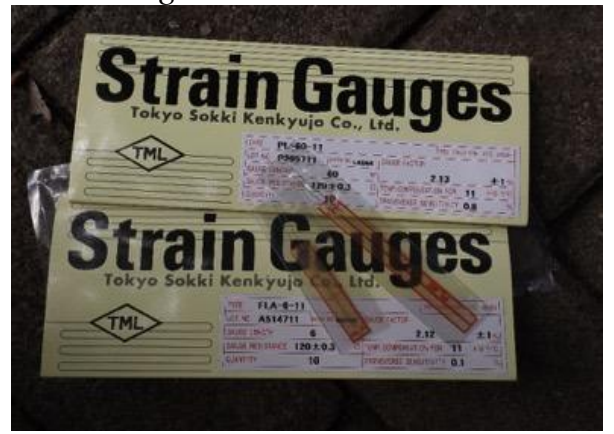

Gambar 3. Strain gauge

c. Strain Meter dan Cable Switch

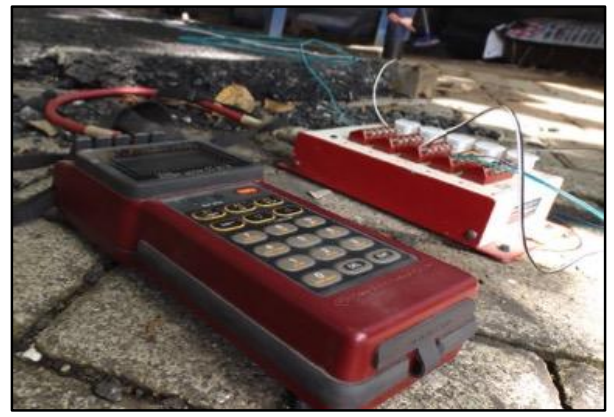

Gambar 4. Strain meter

d. Alat Pengukur Tegangan

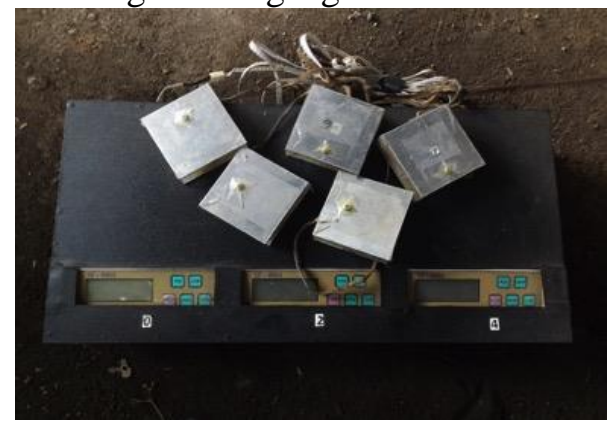

Gambar 5. Alat pengukur tegangan e. Jangka Sorong Digital

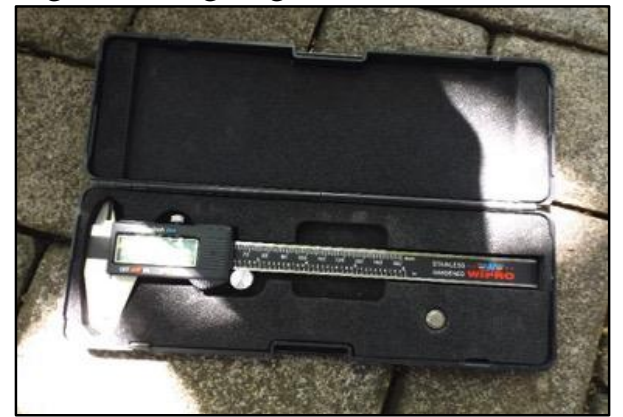

Gambar 6. Jangka sorong digital

4. HASIL DAN PEMBAHASAN

4.1 Hasil Pengukuran Tegangan Dinamis pada Lapisan Pondasi

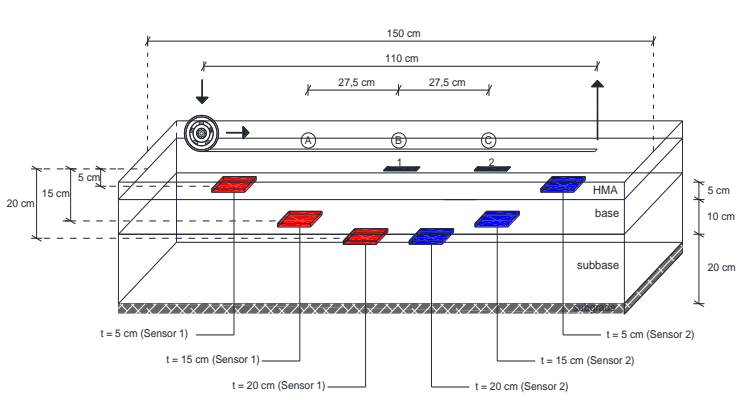

Gambar 7. Lokasi sensor pengukur tegangan

1) Perbandingan Benda Uji Porus 1 dan Benda Uji Konvensional 1

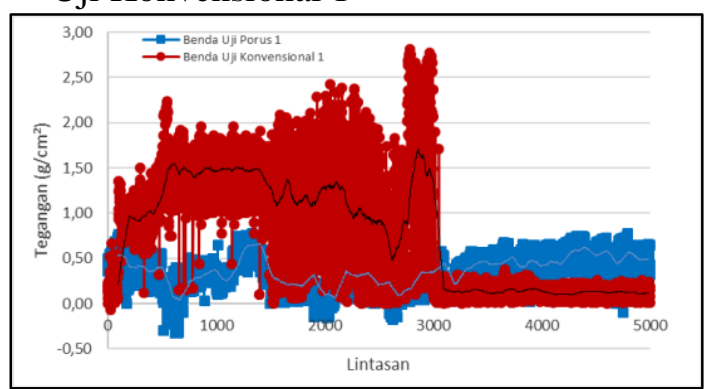

Gambar 8. Tegangan dinamis akibat beban di titik A

Nilai rata-rata tegangan di titik A benda uji porus 1 yaitu $0,370 \mathrm{~g} / \mathrm{cm}^{2}$, lebih kecil dibanding benda uji konvensional 1 , yaitu $0,768 \mathrm{~g} / \mathrm{cm}^{2}$. 


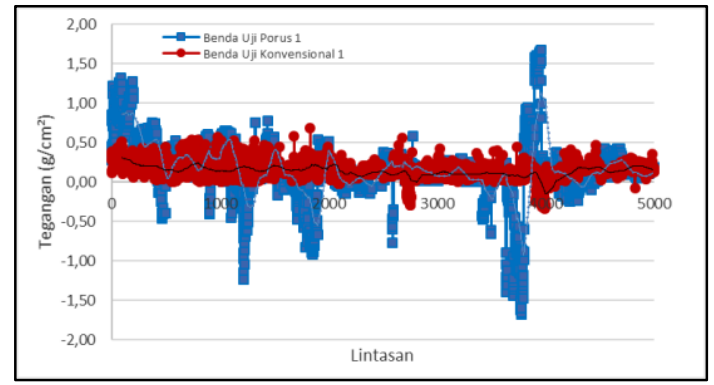

Gambar 9. Tegangan dinamis akibat beban di titik B

Nilai rata-rata tegangan di titik B benda uji porus 1 yaitu $0,153 \mathrm{~g} / \mathrm{cm}^{2}$, lebih besar dibanding benda uji konvensional 1 yaitu $0,138 \mathrm{~g} / \mathrm{cm}^{2}$.

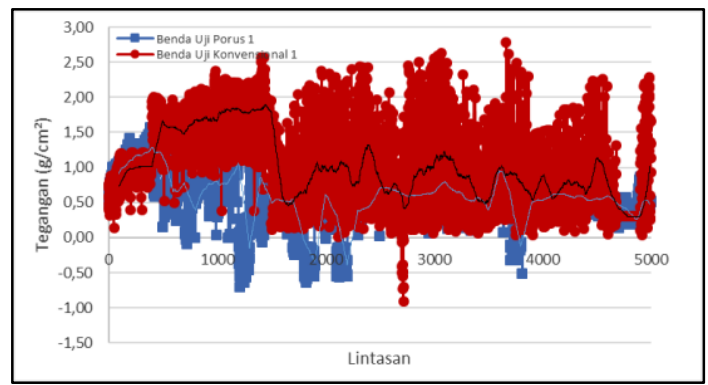

Gambar 10. Tegangan dinamis akibat beban di titik C

Nilai rata-rata tegangan di titik $\mathrm{C}$ benda uji porus 1 yaitu $0,572 \mathrm{~g} / \mathrm{cm}^{2}$, lebih kecil dibanding benda uji konvensional 1 yaitu $1,003 \mathrm{~g} / \mathrm{cm}^{2}$. Gambar 8 hingga Gambar 10 menunjukkan bahwa 2 dari 3 titik acuan pada benda uji konvensional 1 memiliki nilai rata-rata tegangan yang lebih tinggi dibandingkan dengan benda uji porus 1, yaitu titik acuan A dan C.

2) Perbandingan Benda Uji Porus 2 dan Benda Uji Konvensional 2

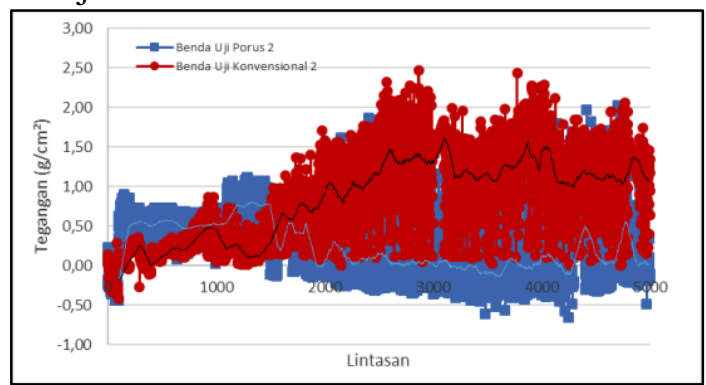

Gambar 11. Tegangan dinamis akibat beban di titik A

Nilai rata-rata tegangan di titik A benda uji porus 2 yaitu $0,229 \mathrm{~g} / \mathrm{cm}^{2}$, lebih kecil dibanding benda uji konvensional 2 , yaitu $0,849 \mathrm{~g} / \mathrm{cm}^{2}$.

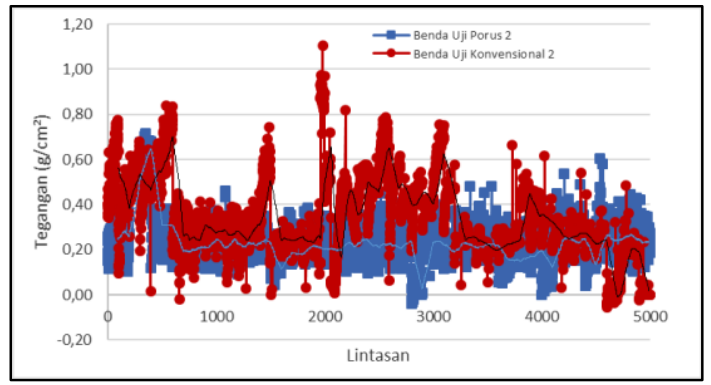

Gambar 12. Tegangan dinamis akibat beban di titik B

Nilai rata-rata tegangan di titik B benda uji porus 2 yaitu $0,228 \mathrm{~g} / \mathrm{cm}^{2}$, lebih kecil dibanding benda uji konvensional 2 yaitu $0,339 \mathrm{~g} / \mathrm{cm}^{2}$.

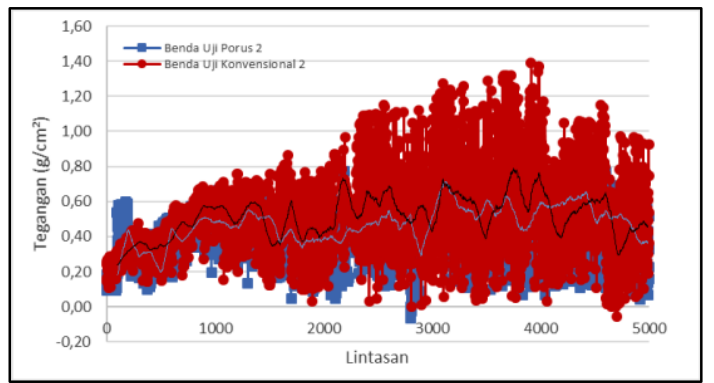

Gambar 13. Tegangan Dinamis Akibat Beban di titik C

Nilai rata-rata tegangan di titik $\mathrm{C}$ benda uji porus 2 yaitu $0,468 \mathrm{~g} / \mathrm{cm}^{2}$, lebih kecil dibanding benda uji konvensional 2 yaitu $0,514 \mathrm{~g} / \mathrm{cm}^{2}$. Gambar 11 hingga Gambar 13 menunjukkan bahwa 3 titik acuan pada benda uji konvensional 2 memiliki nilai rata-rata tegangan yang lebih tinggi dibandingkan dengan benda uji porus 2 .

\subsection{Hasil Pengukuran Tegangan Statis pada Lapisan Pondasi}

1) Perbandingan Benda Uji Porus 1 dan Benda Uji Konvensional 1

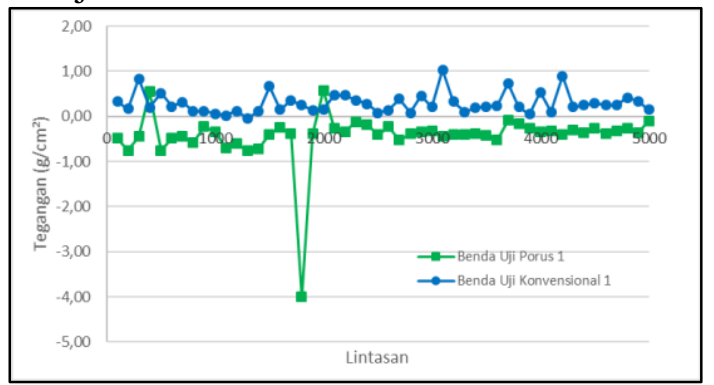

Gambar 14. Tegangan statis akibat beban di titik A

Nilai rata-rata tegangan di titik A benda uji porus 1 yaitu $-0,424 \mathrm{~g} / \mathrm{cm}^{2}$, lebih kecil dibanding benda uji konvensional 1 yaitu $0,289 \mathrm{~g} / \mathrm{cm}^{2}$. 


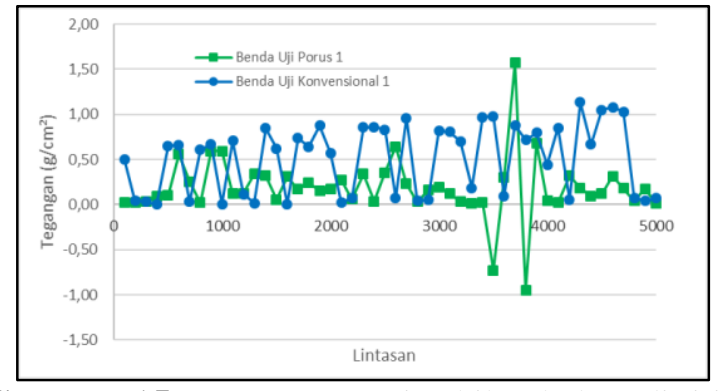

Gambar 15. Tegangan statis akibat beban di titik B

Nilai rata-rata tegangan di titik B benda uji porus 1 yaitu $0,183 \mathrm{~g} / \mathrm{cm}^{2}$, lebih kecil dibanding benda uji konvensional 1 yaitu $0,510 \mathrm{~g} / \mathrm{cm}^{2}$.

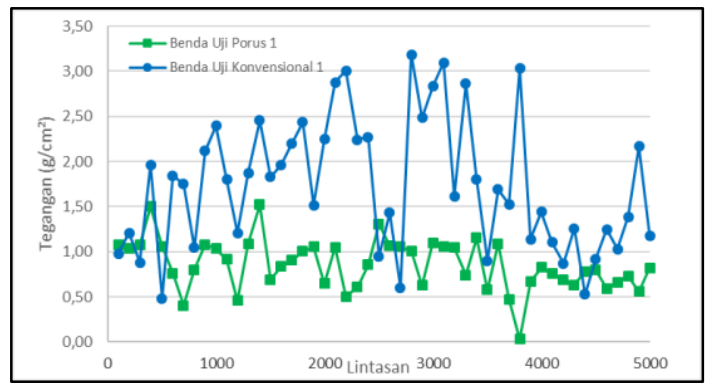

Gambar 16. Tegangan statis akibat beban di titik C

Nilai rata-rata tegangan di titik $\mathrm{C}$ benda uji porus 1 yaitu $0,856 \mathrm{~g} / \mathrm{cm}^{2}$, lebih kecil dibanding benda uji konvensional 1 yaitu $1,737 \mathrm{~g} / \mathrm{cm}^{2}$. Gambar 14 hingga Gambar 16 menunjukkan bahwa 3 titik acuan pada benda uji konvensional 1 memiliki nilai rata-rata tegangan yang lebih tinggi dibandingkan dengan benda uji porus 1 .

2) Perbandingan Benda Uji Porus 2 dan Benda Uji Konvensional 2

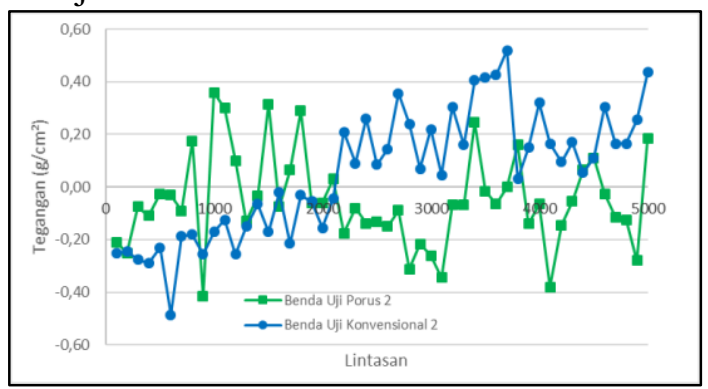

Gambar 17. Tegangan statis akibat beban di titik A

Nilai rata-rata tegangan di titik A benda uji porus 2 yaitu $-0,052 \mathrm{~g} / \mathrm{cm}^{2}$, lebih kecil dibanding benda uji konvensional 2 yaitu $0,050 \mathrm{~g} / \mathrm{cm}^{2}$.

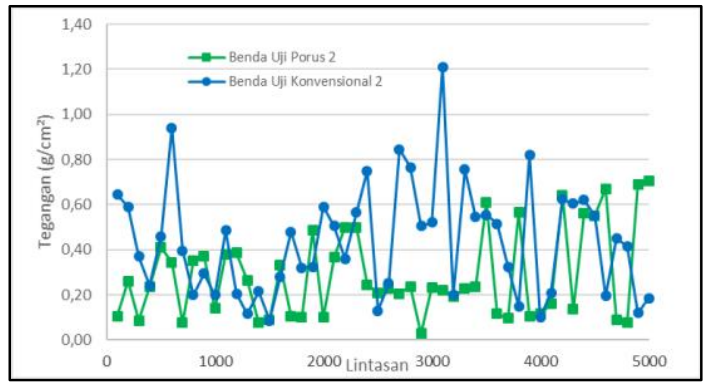

Gambar 18. Tegangan statis akibat beban di titik $\mathrm{B}$

Nilai rata-rata tegangan di titik B benda uji porus 2 yaitu $0,284 \mathrm{~g} / \mathrm{cm}^{2}$, lebih kecil dibanding benda uji konvensional 2 yaitu $0,436 \mathrm{~g} / \mathrm{cm}^{2}$.

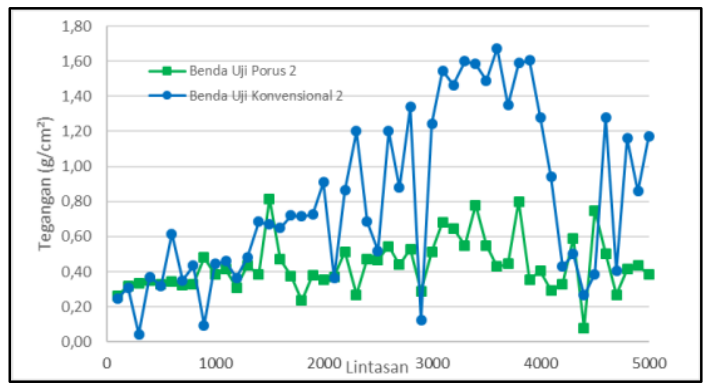

Gambar 19. Tegangan statis akibat beban di titik C

Nilai rata-rata tegangan di titik $\mathrm{C}$ benda uji porus 2 yaitu $0,435 \mathrm{~g} / \mathrm{cm}^{2}$, lebih kecil dibanding benda uji konvensional 2 yaitu $0,812 \mathrm{~g} / \mathrm{cm}^{2}$. Gambar 17 hingga Gambar 19 menunjukkan bahwa 3 titik acuan pada benda uji konvensional 2 memiliki nilai rata-rata tegangan yang lebih tinggi dibandingkan dengan benda uji porus 2 .

\subsection{Hasil Pengukuran Regangan Dinamis pada Perkerasan Lentur}

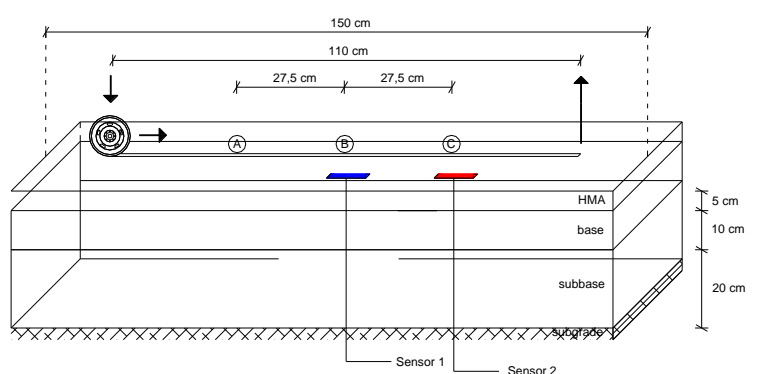

Gambar 20. Lokasi sensor pengukur regangan 
1) Perbandingan Benda Uji Porus 1 dan Benda Uji Konvensional 1

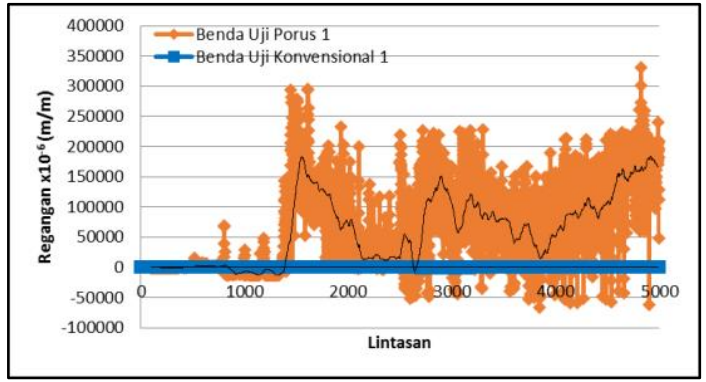

Gambar 21. Regangan akibat beban dinamis di titik B

Nilai rata-rata regangan di titik $B$ benda uji porus 1 yaitu $6,3 \times 10^{-2} \mathrm{~m} / \mathrm{m}$, lebih besar dibanding benda uji konvensional 1 yaitu 4,5 $\mathrm{x}$ $10^{-5} \mathrm{~m} / \mathrm{m}$.

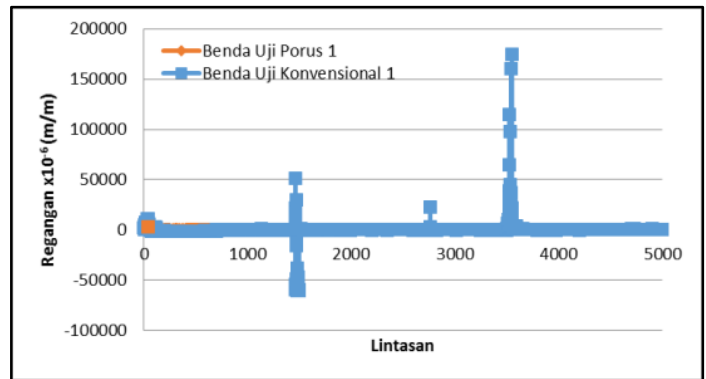

Gambar 22. Regangan akibat beban dinamis di titik C

Nilai rata-rata regangan di titik $\mathrm{C}$ benda uji porus 1 yaitu $6,7 \times 10^{-5} \mathrm{~m} / \mathrm{m}$, lebih besar dibanding benda uji konvensional 1 yaitu $-1,4 \mathrm{x}$ $10^{-4} \mathrm{~m} / \mathrm{m}$.

2) Perbandingan Benda Uji Porus 2 dan Benda Uji Konvensional 2

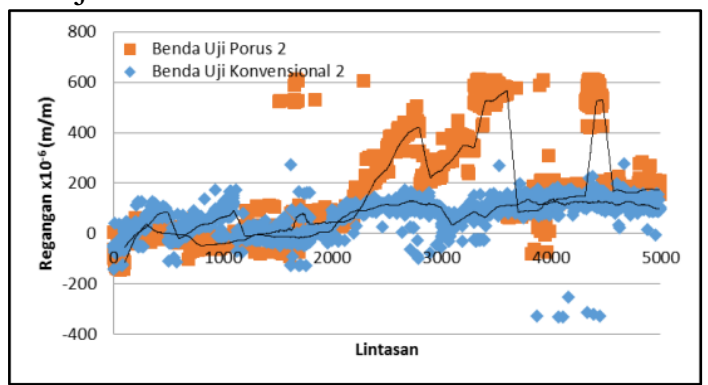

Gambar 23 Regangan Akibat Beban Dinamis di Titik B

Nilai rata-rata regangan di titik $B$ benda uji porus 2 yaitu $1,5 \times 10^{-4} \mathrm{~m} / \mathrm{m}$, lebih besar dibanding benda uji konvensional 2 yaitu $6,8 \mathrm{x}$ $10^{-5} \mathrm{~m} / \mathrm{m}$.

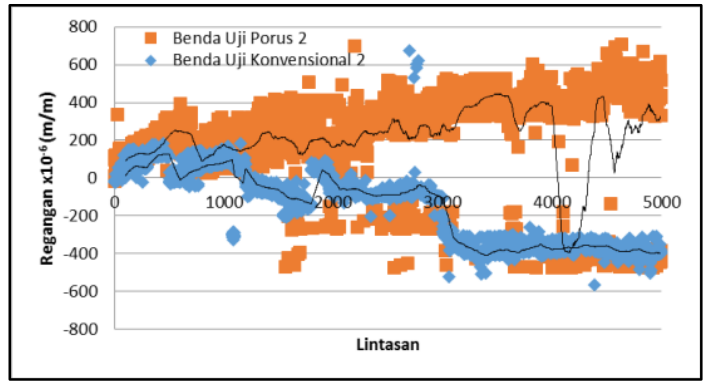

Gambar 24. Regangan akibat beban dinamis di titik C

Nilai rata-rata regangan di titik $\mathrm{C}$ benda uji porus 2 yaitu $2,1 \times 10^{-4} \mathrm{~m} / \mathrm{m}$, lebih besar dibanding benda uji konvensional 2 yaitu $-1,6 \mathrm{x}$ $10^{-4} \mathrm{~m} / \mathrm{m}$.

\subsection{Hasil Pengukuran Regangan Statis pada Perkerasan Lentur}

1) Perbandingan Benda Uji Porus 1 dan Benda Uji Konvensional 1

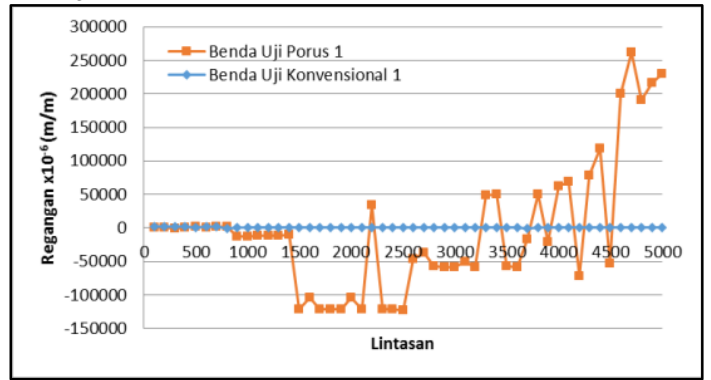

Gambar 25. Regangan akibat beban statis di titik B

Nilai rata-rata regangan di titik $\mathrm{B}$ benda uji porus 1 yaitu $-5,6 \times 10^{-3} \mathrm{~m} / \mathrm{m}$, lebih kecil dibanding benda uji konvensional 1 yaitu 7,2 x $10^{-4} \mathrm{~m} / \mathrm{m}$.

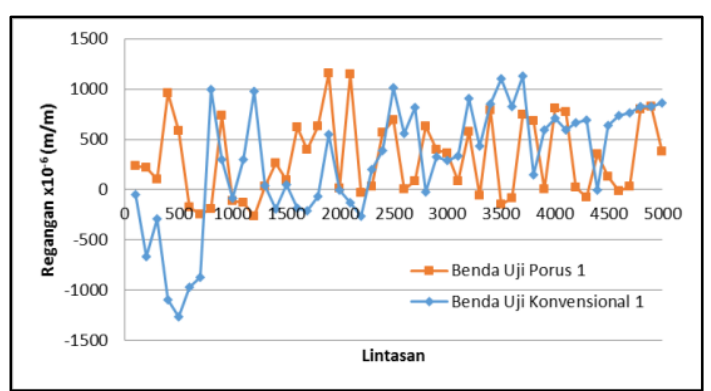

Gambar 26. Regangan akibat beban statis di titik C

Nilai rata-rata regangan di titik $\mathrm{C}$ benda uji porus 1 yaitu $3,1 \times 10^{-4} \mathrm{~m} / \mathrm{m}$, lebih besar dibanding benda uji konvensional 1 yaitu $2,8 \mathrm{x}$ $10^{-4} \mathrm{~m} / \mathrm{m}$. 
2) Perbandingan Benda Uji Porus 2 dan Benda Uji Konvensional 2

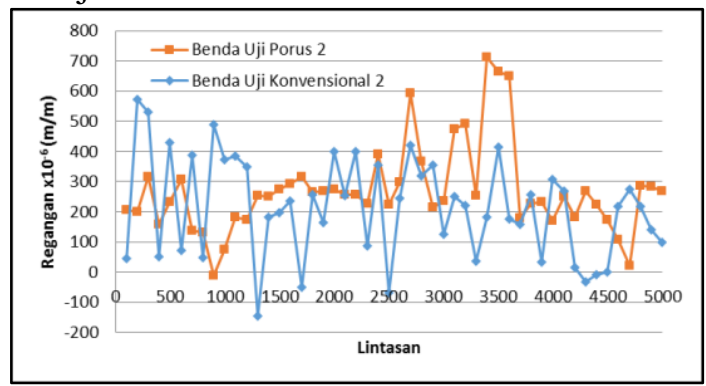

Gambar 27. Regangan akibat beban statis di titik B

Nilai rata-rata regangan di titik $\mathrm{B}$ benda uji porus 2 yaitu $2,7 \times 10^{-4} \mathrm{~m} / \mathrm{m}$, lebih besar dibanding benda uji konvensional 2 yaitu 2,1 x $10^{-4} \mathrm{~m} / \mathrm{m}$.

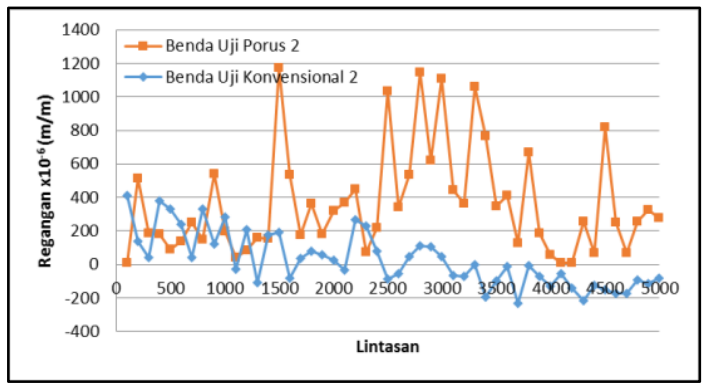

Gambar 28. Regangan akibat beban statis di titik C

Nilai rata-rata regangan di titik $\mathrm{C}$ benda uji porus 2 yaitu $3,6 \times 10^{-4} \mathrm{~m} / \mathrm{m}$, lebih besar dibanding benda uji konvensional 2 yaitu $2,7 \mathrm{x}$ $10^{-5} \mathrm{~m} / \mathrm{m}$.

\subsection{Hasil Pengukuran Deformasi pada Permukaan Perkerasan Lentur}

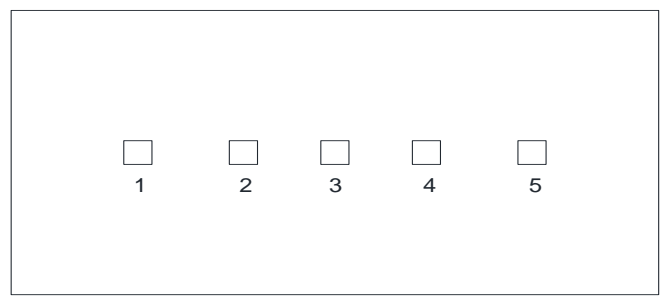

Gambar 29. Letak pengukuran deformasi
1) Benda Uji Porus 1

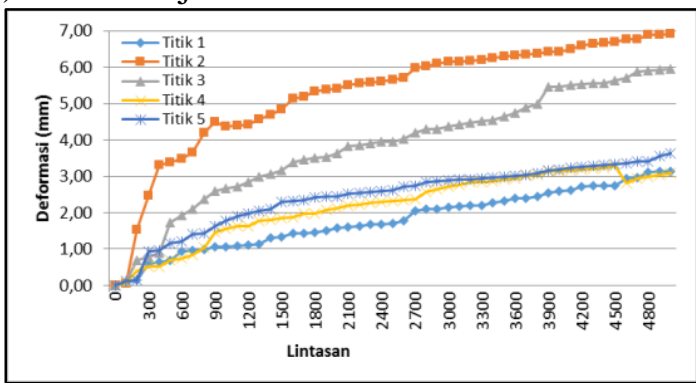

Gambar 30. Hubungan antara deformasi dengan jumlah lintasan

2) Benda Uji Porus 2

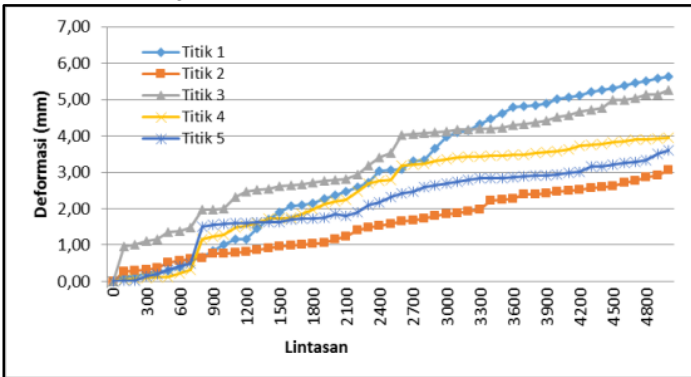

Gambar 31. Hubungan antara deformasi dengan jumlah lintasan

3) Benda Uji Konvensional 1

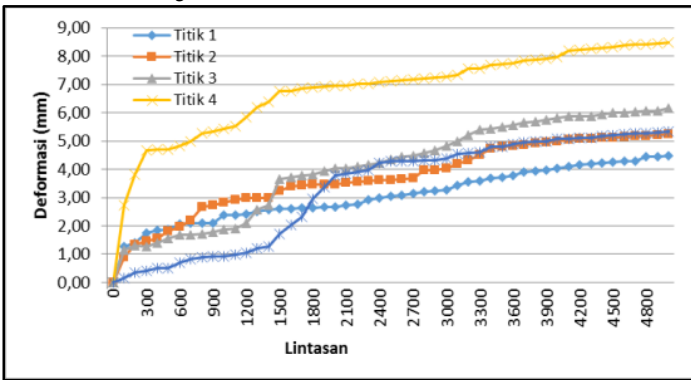

Gambar 32. Hubungan antara deformasi dengan jumlah lintasan

4) Benda Uji Konvensional 2

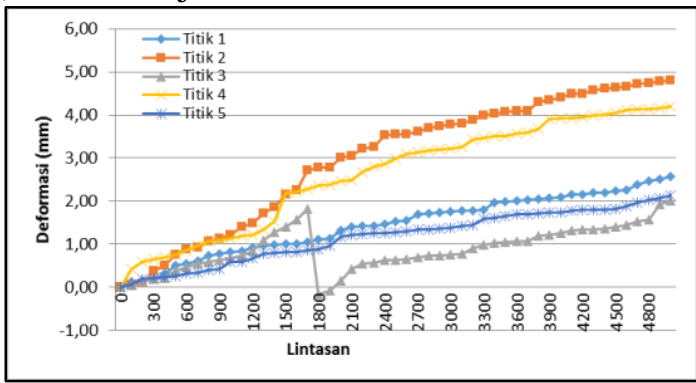

Gambar 33. Hubungan antara deformasi dengan jumlah lintasan 
Dari hasil pengukuran deformasi yang dilakukan terhadap 4 Benda Uji dapat dilihat bahwa besarnya deformasi dari setiap titik tinjau pengukuran cenderung mengalami peningkatan nilai deformasi. Adapun nilai deformasi maksimum pada lintasan ke-5000 terjadi pada benda uji porus 1 sebesar 6,91 mm (titik 2), pada benda uji porus 2 sebesar 5,64 mm (titik 1), pada beda uji konvensional 1 sebesar $8,48 \mathrm{~mm}$ (titik 4), dan pada benda uji konvensional 2 sebesar $4,81 \mathrm{~mm}$ (titik 2).

\section{KESIMPULAN DAN SARAN}

Berdasarkan pembahasan di atas, maka dapat disimpulkan sebagai berikut:

1) Terbukti bahwa terdapat hubungan antara regangan dengan tegangan, pada perkerasan porus apabila nilai regangan besar maka nilai tegangan kecil, sedangkan untuk perkerasan konvensional yang terjadi sebaliknya nilai regangan kecil tetapi nilai tegangan besar.

2) Deformasi yang terjadi pada permukaan aspal akibat beban roda yang melintas semakin bertambah besar seiring dengan bertambahnya jumlah lintasan. Deformasi yang terjadi pada perkerasan lentur porus cenderung lebih besar daripada yang terjadi pada perkerasan lentur konvensional.

3) Tegangan yang terjadi pada perkerasan lentur porus umumnya cenderung lebih kecil dibandingkan pada perkerasan lentur konvensional. Sedangkan regangan yang terjadi pada perkerasan lentur porus umumnya cenderung lebih besar dibandingkan pada perkerasan lentur konvensional.

Untuk penelitian selanjutnya, maka sebaiknya diperhatikan hal-hal berikut:

1) Untuk didapatkan data-data yang valid maka pembacaan data dikembangkan dengan penambahan peralatan khusus yang langsung menghasilkan nilai tegangan dan regangan serta grafik secara elektronik, hal ini akan mempersingkat waktu penelitian dan menghindari kesalahan pembacaan data secara manual.

2) Pada penelitian selanjutnya, sebaiknya sensor dipasang lebih jauh dari titik jatuh roda, agar hentakan akibat beban tidak mempengaruhi tegangan yang diterima oleh sensor tersebut.
3) Untuk lebih mendekati kondisi riil, maka perlu pengembangan alat khusus untuk pengaturan suhu aspal, sehingga penelitian dapat dilakukan lebih mendekati kondisi di lapangan.

4) Setelah dilakukan proses pencampuran material, perlu dilakukan pengujian pengendalian mutu campuran beraspal di lapangan untuk mendapatkan hasil yang lebih realistis.

\section{DAFTAR PUSTAKA}

[1] Amaliyah, E. F., \& Widiningrum, T. A., Analisa Tegangan Dan Regangan Pada Perkerasan Porus Dengan Skala Semi Lapangan Dan Software Ansys, Jurnal Mahasiswa Jurusan Teknik Sipil Vol.1, No.3, 2014

[2] Bina Marga, Spesifikasi Umum Perkerasan Berbutir Lapis Pondasi Agregat, Jakarta: 2006

[3] Rachmawati, D. D., \& Dewi, F. R., Analisa Tegangan Dan Regangan Pada Pondasi Perkerasan Porus Dengan Skala Semi Lapangan Dan Software Ansys, Jurnal Mahasiswa Jurusan Teknik Sipil Vol.1, No.2, 2015

[4] Riyana, R. E., \& Arung, V. N., Analisis Tegangan, Regangan, Dan Deformasi Pada Perkerasan Lentur Porus Dan Konvensional Dengan Skala Semi Lapangan, Jurnal Mahasiswa Jurusan Teknik Sipil Vol.1, No.1, 2017

[5] Tanzadeh, J., \& Shahrezagamasaei, R., Laboratory Assessment Of Hybrid Fiber And Nano-Silica On Reinforced Porous Asphalt Mixtures, Construction and Building Materials, 2017: 260-270

[6] Zhang, Y., van de Ven, M. F., .Molenaar, A. A., \& Wu, S. P., Assessment Of Effectiveness Of Rejuvenator On Artificially Aged Porous Asphalt Concrete, Construction and Building Materials, 2016: 286-292 